\title{
AFRICA AND THE IDEA OF INTERNATIONAL SOCIETY
}

\author{
Yolanda K Spies ${ }^{1}$
}

\begin{abstract}
The shared interests and values of sovereign states prompt them to commit to common rules, conventions and institutions within an inter-subjective "society", where diplomacy is used as main currency. The idea of international society is, however, not unequivocal. Diversification of the identities and interests of an enlarging pool of states - after the Second World War, mostly contributed by Africa-undermines consensus on the rules of engagement. This is aggravated by the history of the aggressive expansion of international society from its traditional European base. African states have generally embraced the traditional norms (such as sovereignty and non-intervention) of international society, but the continent's particular history has informed its inclination to use collective diplomacy (multilateralism) to challenge the structure of a deeply asymmetrical international system. In the process, the parochial part of international society that Africa represents has managed to export certain norms to the "older" members of the society. Of special note is the continent's insistence on horizontal, rather than vertical cooperative relationships, and the fact that development per se has become a fixture on the global diplomatic agenda. The architecture of contemporary universal international society is much more complex and nuanced than ever before, and the role of a sub-society such as Africa-not just in relating to international society, but also in shaping it - is the focus of this article.
\end{abstract}

Keywords: Africa; diplomacy; international society; norms; values; development; post-colonial.

Sleutelwoorde: Afrika; diplomasie; internasionale gemeenskap; norme; waardes; ontwikkkeling; postkoloniaal.

\section{INTRODUCTION}

Contemporary international society only recently assumed universal scope, and remained predominantly Eurocentric until the end of the Second World War. Its large scope arguably encompasses regional international societies, but within the discipline of International Relations (IR) not much has been written on these phenomena (Ndlovu-Gatsheni 2013:22; Hurrell 2004). Africa contains the youngest and most numerous sovereign states of any region in the world, and this article will investigate the continent's collective impact, if any, on the normative discourse within (and about) international society. Given Africa's colonial history and subjugation to traditional international society, a starting question would be whether

1 Senior Research Fellow, SARChI Chair: African Diplomacy and Foreign Policy, University of Johannesburg. E-mail: ykspies@gmail.com 
the continent has been socialised seamlessly into the larger society of states, or whether it is displaying particular behaviour as a sub-society.

Some thought will be given to the ontological discourse around international society, and the disputed Eurocentric nature of its normative framework. This will be followed by a bird's-eye view of Africa's journey into international society; from the continent's ancient status as cradle of humanity and diplomacy (one of the main institutions of international society) to its arrested political evolution as a result of colonisation and its struggle against the exporters of Eurocentric international society, while ironically emulating colonial masters in the process of state-building.

Thereafter, the article will explore Africa's normative imprint on contemporary international society, including the sometimes ambiguous values expressed through collective African diplomacy. Finally, a brief overview of challenges to Africa's diplomatic capacity will be provided, as part of consideration about the extent to which the continent is endowed with the main "currency" of international society.

\section{THE (CONTESTED) IDEA OF INTERNATIONAL SOCIETY}

"International society" was first placed at the core of IR theorizing by proponents ${ }^{2}$ of the so-called English School, who invoked the rationalist political thought of classical legal philosophers such as Grotius and Vattel (Linklater 2010:1). The idea presupposes the co-existence of distinct political communities that recognise a common destiny and share values and interests. This forms the basis for cooperative behaviour and the establishment of certain rules of engagement, which contribute to the stability and order of the society (Bull 1977:13, 172; Sofer 1988:207). Much as a national society shares ideals (typically expressed in the Constitution of a state), an international society embraces values that benchmark the behaviour of its members.

The concept of international society may be abstract, but its practical manifestation lies in tangible institutions: intergovernmental and other international organisations, trade regimes, the body of international law, and diplomatic protocol are just some of the elements which comprise the modern architecture of international society. Diplomacy - which both predates and transcends international society, and which is a practice as old as humanity - is one of its main institutions. The raison d'être of diplomacy is representation, communication, and intermediation; ${ }^{3}$ all of which are anchored in the principle of reciprocity (Cohen 2001:25). As Kalevi Holsti

2 Theorists such as Hedley Bull and Martin Wight were English School pioneers. Their more recent intellectual successors in the domain of International Society (scholars such as Tim Dunne, Barry Buzan, Nicolas Wheeler and Robert Jackson, to name a few) can be found in various IR sub-disciplines, including constructivism.

3 Iver Neumann (2005:72), for example, describes diplomacy as a "third culture" i.e. a culture that mediates among and connects diverse political cultures. Rebecca Adler-Nissen (2015:24) 
(2004:195) says, diplomatic ideas, "help promote confidence, stability, predictability, and the trust that are the foundations" of a stable international environment. In an international system with no central authority, reciprocity reduces risk by creating order, predictability and stability (Langhorne 1998:148). There is, therefore, no such thing as "unilateral" diplomacy; much as a single state cannot presume to be an intergovernmental organisation on its own. Both diplomacy and international society exist only inasmuch as there is a mutually recognised and valued relationship.

The procedural conventions of diplomacy are of universal practical value to international society, but essential to weak or new states because they are more vulnerable in an environment of international anarchy (Hurrell 2004; Sofer 1988:202). Beyond the practical value, diplomacy bestows identity and legitimacy on states, regardless of their relative power in the global arena. Its mutually recognised conventions and procedures are based on a shared ethic of equal status before the (international) law, and young states - the majority of which are African - validate their sovereignty through active participation in summitry and multilateral diplomacy. Beyond new or weak states, the symbolism of diplomacy is so powerful that even the most errant (or hegemonic) of regimes always returns to diplomacy to secure its membership of international society.

Convention within international society is guided by custom, long-term values and unspoken, as well as codified rules of interaction. The behaviour of members is therefore socialised, i.e. transmitted from older to newer members, encouraging the youngsters to "mature" within the society and to "fit" in. This does not preclude constant norm contestation, even among settled members of the society. One such debate is between pluralists and solidarists, with the latter insisting that individuals be considered custodians of international society, rather than sovereign states - as espoused by pluralists (Linklater 2010:2, 9).

The debate on the Responsibility to Protect (R2P) is emblematic of the fact that there is no consensus on the extent to which international society should enforce its norms, or even what exactly those norms entail (Bellamy 2015:161-162; Chimni 2013:1). As Paul Sharp (2009:34) notes, "international societies, like other societies, may appear as settled affairs waiting for some great exogenous shock to unsettle and transform them. They are, however, sites of continual arguments about how life is and ought to be organised".

Apart from the "continual arguments", contemporary international society itself is rife with an even more divisive discourse; one that follows a "them and us" template. One only has to skim IR literature to find ubiquitous reference to different "worlds" - as though human polities do not share a single universe (Puchala 1998:150; Rothgeb 1995:34). Samuel Huntington’s (1996) hypothetical

adds the caveat that, "while diplomacy successfully mediates differences, it does not necessarily address root causes of a crisis (it may sometimes even prolong it)". 
"clash of civilisations" caused much controversy but the theme was nevertheless placed on the global diplomatic agenda when the United Nations General Assembly unanimously declared 2001 to be the "United Nations Year of Dialogue among Civilizations" (UNGA 2001).

Indeed, several commentators have questioned the idea that international society is a monolithic construct. Theorists such as Der Derian (1987:2-3) and Jönsson and Hall (2005:33) point out that traditional IR theory is steeped in Eurocentric thought and liberal ideas about the world. The status quo therefore does not reflect normative consensus on the rules of engagement at the global level. Moreover, there can hardly be agreement on structural order and ideal-type conduct when the vast majority of the world's states are not "Western", and trace their statehood to a relatively recent struggle against colonial oppression by Western states. The "young" members of international society take umbrage at the idea that they have been socialized (or more gallingly, "civilised") into international society as reward for displaying European-style behaviour, when history shows that such behaviour was forced on them through mercantilism and colonialism (NdlovuGatsheni 2013:21; Neumann 2005:72-73; Zarakol 2014:312). Western agency within international society is therefore not necessarily normative, just as nonWestern norm entrepreneurship is not necessarily a paradox. There are lessons on issues such as identity, dependency and state-building that are not only applicable to the non-Western world, but might well be heeded by Europe itself - the recent "Grexit"4 crisis comes to mind.

The problem with the presumed schism(s) in international society is that a sense of "them versus us" develops - something that is anathema to the idea of a universal international society. It does play up to an even greater extent, however, the importance of its key institution, diplomacy, which per definition is a constant bridging endeavour that seeks to transcend divisions among human polities and construct a global commons (Adler-Nissen 2015:27).

But diplomacy (in and of itself a neutral medium - a "vehicle" - of representation and communication) can become conflated with the substance of its message when it insists on a right to particularism. Shaw (2008:42) mentions, as example, excuses for human rights abuses and prevention of international scrutiny thereof. In the case of Africa, occasional hints at exceptionalism within international society have become associated with the continent's obsession with solidarity, which prevents peer pressure on deviant leaders.

4 "Grexit", a portmanteau word, refers to the controversial potential exit of Greece from the Eurozone monetary union, on account of its large public debt. 


\section{AFRICA'S MEMBERSHIP OF INTERNATIONAL SOCIETY: THE JOURNEY}

Africa can rightly claim to be the birthplace of the main institution of international society; in its capacity as cradle of humankind, it is the continent where diplomacy began. When human societies started to coalesce and differentiate from each other, they required a modus vivendi, and this was facilitated by the development of language as a medium of human communication. The movement from nomadism to permanent settlements was an important catalyst, because permanently settled areas required at least rudimentary systems of governance and functional relations across borders to negotiate with other authorities. Dan Nanjira (2010 Vol. 2:119) explains that such contact, "brought diplomatic ways of settling differences among groups of peoples via alliances, compensatory means of dialogue, cooperation, consensus, compromise and coordination of efforts for development and peaceful coexistence". The nascent diplomacy provided an early mechanism to "level the playing field" and to facilitate interaction among extremely diverse communities.

The earliest recorded diplomacy in Africa was practised during antiquity by the Egyptians. At the height of its imperial power, the so-called "Amarna letters" (inscribed on cuneiform tablets) recorded relations between Egypt and its neighbours. An early example, dating back to about $1100 \mathrm{BCE}$, is a treaty between Egyptian Pharaoh Rameses II and the King of the Hittites (in Anatolia, what is now known as Turkey). This codified agreement represented the first ever recorded peace treaty in the history of humankind (Marsh 2013:59; Shaw 2008:14). Most history books concentrate on Egypt's diplomacy within the Middle East (with Babylon, Assyria, Mesopotamia and Canaan) and the Bible (1 Kings 3:1) recounts how Israeli King Solomon, "made an alliance with the King of Egypt by marrying his daughter". Beyond Egypt, several instances of diplomacy involving other African kingdoms were recorded; involving Egypt's neighbours to the South, including Ethiopia and Nubia (modern-day Sudan/Ethiopia/Eritrea), and the tribes of what would eventually become Libya to the west of Egypt. A legendary diplomatic link (accounts of which appear in both the Old and New Testaments of the Bible, the Talmud and the Quran) connects King Solomon with Sheba, the "Queen of the South", identified by many ${ }^{5}$ scholars as a Queen of Ethiopia.

Notwithstanding voluminous diplomacy during antiquity, Malcolm Shaw (2008:16) explains there was not yet (in Africa or elsewhere) a conception of "international society" - if the latter presupposes a community of political entities

5 Queen Sheba's visit to King Solomon is contained in many historical accounts, but is also the theme of various myths. Some scholars believe she originated from the southern Arabian Peninsula, the current Yemen. 
that co-exist peacefully within an international order structured by a defined institutional and legal framework.

Even though the rich tapestry of African diplomatic history since antiquity has not been fully recounted, there is ample confirmation (in oral histories and anthropological evidence) that diplomacy was practised across the continent. It was marked by extensive negotiations (to settle disputes or establish political alliances, trade or frontiers), elaborate ceremonies, and the deliberate linkage of separate political communities through symbolic acts, such as intermarriages (Nanjira 2010 Vol. 1:106). Importantly, several of the norms and conventions of contemporary international society were already in evidence. Sophisticated diplomatic protocol was observed, including the exchange of gifts and presentation of credentials, and legal norms, such as the immunity of envoys and the honouring of treaties were observed (Irwin 1975: 82). Pacta sunt servanda (the sanctity of treaties) has proven to be an ancient and universal norm and would, in time, become indispensable to the development of a society of states.

During pre-colonial Africa, intra-African diplomacy was as vibrant as continental relations with the outside. We are aware, courtesy of early traders, missionaries and other travellers, of fascinating exchanges among many of the polities: Aksum, Buganda, Timbuktu, Mali, Ghana ${ }^{6}$ (Wagadu), Oyo, Asante ${ }^{7}$, Dahomey (now Benin), Mapungubwe, Great Zimbabwe, to name but a few. Arguably, pre-colonial Africa was set to evolve into a continental international society, much as post-Westphalian Europe did. But as Nanjira (2010 Vol. 1:118) laments, "Africa lost a golden opportunity and 'missed the boat' in the Middle Ages - a unique era in world and African history that offered unique opportunities for learning from past mistakes as medieval times demonstrated. Africa, with all her flourishing kingdoms, empires, super empires and city states already in medieval times, was ripe for cementing foundations for her future internal and external relations with other political entities". One could speculate that Europe, following its own dark ages, benefited from the central authority exerted by the Catholic Church, and that this theocratic organisation paved the way for a secular society of states. But in the case of Africa it is counterfactual speculation, and this article is not part of that debate.

Most commentators would agree, however, that European imperialism dislocated Africa's political evolution. Whilst it would be unfair to claim that Europeans were the only foreigners to exploit Africa (then or now), and notwithstanding the fact that the great powers pursued the three "Gs" (glory, gold and gospel/God) across the

6 The Kingdom of Ghana should not be confused with the contemporary state of Ghana. The former was located much more north in West Africa, encompassing inter alia some of the territory now part of Mauritania and Mali. 
non-European world, Africa suffered more structural damage than any other part of the world.

The scramble for Africa and the rampant slave trade ${ }^{8}$ from Africa to other parts of the world were eventually checked by the rise of humanitarian thought in law, politics and philosophy. Towards the end of the $18^{\text {th }}$ century, boosted by efforts to abolish the slave trade, the "Back to Africa Movement" was started by freed slaves in the United States. Decades later, in 1847, it resulted momentously in the founding of the African state of Liberia - literally, "free place". But the century was to reach yet a new low in proprietary greed. At the Berlin Conference of 1884-1885, the major powers of Europe simply divided the "dark continent" among themselves. The arbitrary boundaries were not imposed on terrae nullius: remotecontrolled borders destroyed the social and political cohesion of the subjugated peoples, and demarcated artificial future component parts of African international society (Hamalengwa et al. 1988:137; Ndlovu-Gatsheni 2013:21; Rodney 1973).

Most African states remained colonized until the latter half of the $20^{\text {th }}$ century. During this extended period of colonisation (longer than that experienced by any other region) nascent African states were infused with the political culture of their colonisers. At the same time - albeit paradoxically, seeing that they were not respected as independent actors - they were socialised into the norms of Eurocentric international society.

In wry depiction of the colonial metaphor, it was mostly in Europe ${ }^{9}$ that African intellectuals, activists, and community leaders assembled during the first half of the $20^{\text {th }}$ century, attempting to concretise their Pan-African aspirations. Starting in London in 1900, the Pan-African conferences morphed into a series of more formal congresses from 1919. The seminal Fifth Pan-African Congress was held in Manchester in 1945, and it was there that key resolutions were adopted, outlining the participants' vision of a post-war, post-colonial dispensation in Africa, free of racism or any other oppression (Ndlovu-Gatsheni 2013:24; Nanjira 2010 Vol. 1:128). This vision corresponded with traditional African cultural values such as "ubuntu" (Nguni word for humaneness) and "Harambee" (Swahili word for pulling together) which downplay the importance of geopolitical borders, and are used in the political sense to prioritise community, selflessness and respect for tradition and continuity. But Pan-Africanism, a norm that conjures up a "whole" and healed continent, has also fed into one of the most divisive discourses in African diplomacy, namely the post-colonial political integration of the continent.

8 Sadly, many Africans were also complicit in this monstrous trade.

9 It was only as from the 1970 s that these congresses were held in Africa, starting with the $6^{\text {th }}$ PanAfrican Congress in Dar es Salaam, in 1974. The $7^{\text {th }}$ Congress took place a full 20 years later, during 1994, in Kampala. 
This became clear during the early 1960s, when the Casablanca Group ${ }^{10}$ of African leaders advocated for radical integration of the continent, with the vision of establishing a "United States of Africa". Charismatic leadership within this group (inter alia by statesmen such as Kwame Nkrumah of Ghana, Gamal Abdel-Nasser of Egypt and Sékou Touré of Guinea) ensured that the idea has persisted in African diplomatic rhetoric over the past half-a-century, despite the fact that it has not been implemented at any level.

It is important to note that the Casablanca Group had the greatest aversion to the seamless absorption of Africa into a universal international society. They were outnumbered, however, by the moderate Monrovia Group (led by Nigeria and Liberia) and the 12-member Francophone Brazzaville Group that sought a sovereign state-centric (rather than federal) continental dispensation. Thus, when Ethiopian Emperor Haile Selassie convened a summit of African leaders in Addis Ababa during May 1963, the organisation that was founded - the Organisation of African Unity (OAU) - was premised on the prevailing norms of contemporary international society. In time, its greatest success would be to oversee decolonisation. Its most passionate and unified position concerned the struggle against apartheid in South Africa, where institutionalised white-on-black oppression represented a microcosm of colonialism's racial profile.

The Pan-Africanist ideals were, however, diluted by the individual statebuilding projects of its members, overlapping sub-regional integration projects and, as Ndlovu-Gatsheni (2013:25) observes, African states' enthusiastic membership of other communities of states (such as the Commonwealth) that did not share the sentiments of Pan-Africanism. Following the end of the Cold War, during which Africa was widely used as an arena for ideological proxy wars, a new generation of Pan-Africanists revived the continental project. Under the leadership of Thabo Mbeki from South Africa, Olusegun Obasanjo from Nigeria and the eccentric Muammar Ghaddafi from Libya, the OAU was dissolved to make space for a better capacitated organisation, the African Union (AU), with a wider mandate to take charge of peace and security, development and continental integration. One of its first projects was to establish a Pan-African Parliament.

\section{AFRICA AND THE NORMS OF INTERNATIONAL SOCIETY}

It is in the dreadful history of the $20^{\text {th }}$ century that the contemporary norms of international society took shape. The First World War (1914-1918) spawned intellectual reflection on traditional or "old" diplomacy; the exclusive, secretive and (mainly) bilateral European diplomacy that was widely seen as having caused the

10 The Casablanca Group comprised of seven countries: Algeria, Egypt, Ghana, Guinea, Libya, Mali, and Morocco. 
"Great War", thereby destroying European international society and plunging the world into catastrophe. Led by leaders from an increasingly assertive "New World", calls were made for "new" diplomacy; transparent and accountable relations among the members of a universally inclusive international society. This idea was embraced by the nascent states of the colonised regions, Africa in particular, and paved the way for the normative prioritization of multilateral diplomacy. One of the driving ideals was that international society would find structure in a permanent institution with universal membership. It was an African leader, South African General Jan Smuts, who during 1918 came up with the first set of proposals for such a "League of Nations" (Smuts 1918:vi). His ideas were propagated by, for instance, the United States of America (US) President Woodrow Wilson, and the result was the founding of the League of Nations at the Paris Peace Conference in 1919 - coinciding with the first Pan-African Congress meeting.

The League did not live up to its founding ideals and it was only after World War II, in 1945, that a multilateral organization of truly universal character was established. The same Jan Smuts who had envisaged the League three decades earlier drafted the Preamble of the United Nations (UN) Charter. He made a case for the explicit inclusion of values in the Charter, to add a normative dimension to the legal-bureaucratic content (Heyns 1995:334). The double irony cannot be missed - this normative contribution to international society by a leader of an African country, of which there were only four ${ }^{11}$ independent enough to be founding members of the UN; and specifically a leader of South Africa, which would soon thereafter become an outcast of international society on account of its eschewing the norms of that society. Seventy years later, the UN's "demographics" have reversed and Africa's 54 members are more than a quarter of the organisation's membership - a larger representation than any other region on earth. And South Africa, on account of individual statesmanship and the country's rehabilitation into international society, has once again assumed a prominent position within the $\mathrm{UN}$ family.

In the seven decades since the UN's founding, Africa has played an increasingly instrumental role in the crystallization of new norms within international society, and the most poignant of these stem from the continent's yearning for justice and equality in international relations. This reflected in its insistence on a right to development - an idea first placed on the global diplomatic agenda by Doudou Thiam, the Foreign Minister of Senegal, in a speech to the General Assembly on 23 September 1966 (Whelan 2015). This demand fuelled the increasingly bitter debate that ensued about the asymmetrical, patronizing relationship (reminiscent of historical relations) between donors and aid recipients. African states were offended

11 Egypt, Ethiopia, Liberia and South Africa were the only four African states among the 51 founding members of the UN. 
by the idea of a "normative hierarchy" that would justify aid being wrapped in conditionality, while they saw themselves as having been exploited in the developed world's quest for wealth and rapid industrialisation. As from the late 1970s the reality of impoverished states being coerced into structural adjustment programmes (SAPs) at huge social and political cost, became all too common in Africa.

At a rhetorical level, the right to development became less controversial towards the end of the 20th century, with the norm echoed in many global and regional declarations. A breakthrough was the 1986 adoption by the UN General Assembly of the Declaration on the Right to Development, which described development as an "inalienable human right". The then UN Secretary-General Kofi Annan's Millennium Report in 2000 expanded on the concept. Calling his report, "We, the Peoples" (echoing Smuts' words in the Preamble), he named sustainable development as a fundamental human freedom. This, in turn, inspired the UN's Millennium Declaration of September 2000 that set the historic Millennium Development Goals (MDGs). The unanimous adoption of the MDGs represented the pinnacle of diplomatic institutionalisation of the right to development, committing international society (through Goal Eight) to a "global partnership for development".

Two decades into the $21^{\text {st }}$ century, the debate is moving decisively away from the patronizing, unilateral traditional semantics associated with official development assistance. The preferred term is now "International Development Cooperation" (IDC), and the debate is reproduced within Africa (and wider, within the global South), to reflect "horizontal" development cooperation among developing states. Within the Southern African Development Community (SADC), for example, the majority of ministries of foreign affairs have recently been renamed ${ }^{12}$ to reflect the importance of cooperation. They seem to have institutionalised a normative element of international society, pioneered by Africa; the notion of cooperation as equals, to level the developmental playing field.

An area of norm-entrepreneurship where Africa has a less glowing record, is the new global security paradigm known as human security - even if individual African leadership within international society has placed the norm at the centre of the peace and security-development nexus. The first ever UN Secretary-General from Africa, Egyptian Boutros Boutros-Ghali, inserted the idea that peace can be "built" proactively, when he released his 1992 report "Agenda for Peace". Boutros-Ghali was especially mindful of the scourge of intractable intra-state conflicts in his home-continent, and sought greater investment by international

12 The foreign ministries of Botswana, DRC, Malawi, Mozambique, Namibia, South Africa, Swaziland and Tanzania have all thus been renamed. Of course, a name-change might indicate a rhetorical shift, but is no guarantee of those ministries having effected substantive changes in terms of their actual conduct or budgetary prioritisation. 
society in addressing the root causes of conflict. Also in the UN context, veteran Algerian diplomat Lakhdar Brahimi captured the realities of post-Cold War peace and security challenges in his 2000 report (the "Brahimi Report") on "United Nations Peace Operations", with wide-ranging recommendations on institutional reform. Under the leadership of Boutros-Ghali's successor, the second African UN Secretary-General Kofi Annan, the concept of peace-building was finally institutionalized in the form of the new UN Peace-Building Commission. Annan's 2005 report "In Larger Freedom" (the title once again echoing the rhetoric of the Preamble to the Charter) identified the need for structural change to the UN peace and security architecture.

A decade earlier, Sudanese diplomat-scholar Francis Deng had pioneered the linkage between sovereignty and responsibility in his 1995 article, "Frontiers of Sovereignty", providing a foundation for the subsequent development of the doctrine of R2P. The now accepted idea that under-development, poverty and economic and political marginalisation constitute root causes of conflict, and the AU's specific mandate under Article 4(h) of its Constitutive Act (2000) to intervene in humanitarian crises, have not translated into African governments' prioritising the security of their citizens, rather than that of their regimes. Despite the AU's adoption of a range of normative frameworks (the 2007 African Charter on Democracy, Elections and Governance is a notable example), in practice the continent's leaders have been loath to confront errant African governments. Instead, what is common is a "live-and-let-live" attitude toward political peers that Macaulay Kanu (2010:152) says is a guiding principle of human relations in Africa.

Ironically, this laissez faire approach to conditions in fellow African states links into the traditional, Eurocentric international society's conjoined values of sovereignty and non-intervention. At the same time, however, it reflects the contemporary international society norm of inclusivity. In the African context, inclusivity has manifested as "collectivity", which draws on deep-rooted African traditions of community and family (Rodney 1973). In its extreme, the collectivist approach can lead to a strategic cul-de-sac (the Ezulwini Consensus ${ }^{13}$ on Security Council reform comes to mind), and paralysis (AU vacillation vis-à-vis the humanitarian crisis in Libya 2011, that gave space for NATO to lead the Security Council-mandated intervention). Collectivity also offers a fraternal fog behind which African despots, such as Muammar Ghaddafi, could hide for decades, and behind which tainted leaders, such as Robert Mugabe and Omar al-Bashir, continue to enjoy impunity. The current spate of "third-termism" (the new African version of

13 Africa is the only region in the world that has formulated a common position on UN Security Council reform, expressed through the AU's 2005 "Ezulwini Consensus". The rigid proposal has, however, stifled the reform debate within Africa, and several African powers (such as South Africa and Nigeria) are now pursuing de facto alternative strategies. 
coups d'état) is an example of self-inflicted legal ambiguity within the international sub-society of Africa (Mulindwa 2015).

Africa's fraught relations with the International Criminal Court (ICC) are a somewhat different case in point. Despite the fact that a majority of African states are signatories to the 1998 Rome Statute, the AU has taken a collective decision to disregard the Court's indictment of incumbent African heads of state (Mutton 2015). The stand-off might seem petulant, but it speaks to a larger legal problem within international society: the fact that permanent UN Security Council members such as Russia, the US and China (none of whom is a signatory to the Rome Statute) have the privileged structural authority to refer cases against individual state leaders (most, thus far, from Africa) to the ICC, while they are sure to veto any referral that affects themselves. As long ago as 1977, Hedley Bull warned that non-Western ideas had to be incorporated into international law (as discussed by Linklater 2010:8) if international society were to become truly universal. Africa is insisting on such a level international legal playing field, and the ICC has become a casualty of that struggle.

\section{DIPLOMACY AS CURRENCY}

Following the logic of international society theory, diplomacy clearly offers universal "currency"14 within the society of states. Post-colonial Africa had deftly organized itself multilaterally in order to make a global impact, but the continent's individual states have been less successful at the conduct of traditional bilateral diplomacy. The speed ${ }^{15}$ and nature of decolonisation during the 1960s meant that one after the other former colony - ready or not - was declared (rather than evolved into) a sovereign state. Amidst the existential angst of having to establish a national identity for the first time, the dearth of indigenous bureaucratic expertise, resources or institutional memory impeded the states' capacity to institutionalize the conduct of diplomacy - a very costly and sophisticated enterprise.

Africa's process of state-building is still in its infancy, and even the creation of new states has not ended: as recently as 2011 yet another African polity - South Sudan - entered the society of states. Most African states are weak (relative to the rest of the members of international society) or struggle to overcome a

14 This is irrespective of the debate about diplomacy's normative credentials.

15 Hamilton and Langhorne (1995: 210) note the case of the Belgian Congo which had a mere six months to prepare for its independence. The authors add that there were two notable exceptions in Africa: Nigeria and Ghana. Ghanaians were included in the governor's 1954 advisory committee on defense and external affairs, which sponsored the recruitment and training of diplomats prior to political independence in 1957. Likewise, the creation of an external affairs department in Nigeria four years before the state's independence in 1960, gave opportunity to Nigerians to work in representative offices abroad. 
democratic deficit, and this makes it difficult for African foreign ministries to professionalise their functions. Diplomats from developed states take for granted their constitutionally protected public institutions, accountable civil services and governments' monopoly over the use of force within inviolate geographical boundaries. African diplomats are far less secure.

Regime insecurity can result in securitisation of diplomacy, and Ronald Barston (2006:71) notes a disproportionately large number of African military personnel hold diplomatic appointments. Even the most legitimate of governments, however, can be subverted when it lacks capacity. Diplomacy, as mentioned, is an expensive enterprise and comprehensive bilateral relations demand the establishment and maintenance of embassies across the world. States that cannot afford to do so, automatically limit their diplomatic footprint. Financial constraints also undermine the ability of states to participate meaningfully in forums of global governance - defaulting on dues to international organisations, for example, can lead to loss of voting rights.

At the individual level, many African diplomats have to contend with jobinsecurity. Weak or erratic national currencies and the spectre of government bureaucracies malfunctioning can leave such diplomats extremely vulnerable. Even with the best of intentions, serving diplomats have to do "more with less", and African diplomats typically have far fewer resources than their peers from other parts of the world. Very few African states can afford the maintenance of well-staffed missions, placing disproportionate pressure on personnel to tend to the full spectrum of functional and/or geographic responsibilities - including, often, simultaneous accreditation to many other countries. Even in the case of multilateral missions, the panoply of caucuses, committees and other coordinating meetings can undermine performance. Jones and Whittingham (1998:6) quote a Zimbabwean ambassador to the UN who remarked, "When we go for negotiations you find that America, for example, has 90 trade officers and poor Zimbabwe just has three officers who are expected to negotiate around the clock [...] that's why you find African officials end up sleeping, when others are negotiating. It's not because they are lazy, they are human too and they get tired". Under-representation in multilateral forums, as Calvert and Calvert (1996:225) warn, means that outnumbered, unskilled negotiators from African states can be "picked off one by one" by stronger negotiating teams from developed countries. The human resources dilemma is exacerbated by lack of an increasingly strategic resource: information and communications technology (ICT); the so-called "digital divide" that has been described by Boutros-Ghali (1994:102) as an economic-technological "iron curtain".

The divide between haves and have-nots is reproduced also at state level, and diplomacy happens to be a prerogative of the exclusive "core" in any society. It is an ancient and universal custom to select diplomats only from the most reputable 
members of a community, and this usually means that they come from a privileged minority. Where indigenous civil servants were trained to represent colonised states in anticipation of eventual independence, a peculiar dilemma presented in the sense that the "natural" elitism of diplomacy became perverted. African career diplomats who were trained by colonial masters typically struggle to shake off the impression that they were co-opted into representing a status quo of structural marginalisation. Dietrich Kappeler (2004:357) explains that the,
diplomatic culture instilled into [diplomats from the post-colonial states] was largely of the traditional sort and frequently not adjusted to new international realities. The result was often that such new diplomats either felt ill at ease and tried to copy an alien approach or, on the contrary, revolted against traditional diplomatic attitudes and attempted to follow "authentic values".

Colonial tutelage is particularly visible within the diplomacy of Francophone Africa, which has preserved a special relationship with France ever since the early 1960s when the Brazzaville Group (led by stalwarts, such as Felix HouphouetBoigny of Côte d'Ivoire and Leopold Sedar Senghor from Senegal) insisted on maintaining the patrimonial relationship. The proxy-French diplomatic culture has persisted in African international relations, and it is only reinforced by the fact that so many leaders and diplomats (and their families) from the Francophonie, are educated in France.

This brings to the fore uncomfortable questions about representation - an element of diplomacy that cannot be delinked from its raison d'etre. Africa's microcosm of international society is linguistically and culturally fractured and unfortunately reminiscent of its colonial history. The deeply political battle preceding the January 2012 election of the first ever Anglophone Chairperson of the African Union Commission, Nkosazana Dlamini-Zuma, was illustrative of this enduring schism in African international (sub)society.

Sadly, African diplomacy is also undermined by pervasive nepotism. In the many African states where personal power is stronger than institutional power, heads of state take advice only from a small group of hand-picked cronies. This has perpetuated the assumption (not just held by non-Africans) that only summitry of executive leaders can move issues forward (Eban 1998:96-97). In West Africa, for example, and as recounted by retired Ghanaian Ambassador, Ebenezer Debrah, there was a period when Francophone countries did not exchange resident ambassadors, because heads of government felt that they met regularly enough to address issues of mutual concern. But this is by no means an isolated phenomenon. As an April 2013 editorial in the Addis Fortune (2013) pointed out, "most of the foreign missions of [Ethiopia] remain understaffed. Political loyalty is given priority over other indicators, in the appointment of mission heads and members. Upward mobility of professionals is sluggish and hardly merit-based". 
The situation has improved in many African states, but much work needs to be done. Professionalisation of diplomacy is crucial if Africa wants to maximise its leverage of this international society "currency".

\section{CONCLUSION}

Contemporary universal international society has been in existence only since the end of the Second World War. Its manifestation coincided with the diplomatic awakening of an entire continent - Africa - that had previously been excluded from Euro-centric international society. African states, most of whom had their political borders arbitrarily imposed, nevertheless enthusiastically embraced the classical norms of pluralist international society, specifically the implementation of uti posseditis to stabilize borders, and the doctrine of sovereignty and nonintervention. The African diplomatic project was initially driven by Pan-Africanism, but individual state-building projects soon overshadowed the realisation of these ideals. It is perhaps fitting that development itself became a leitmotiv in African diplomacy, as the continent proceeded in its collective diplomatic endeavours to challenge the structure of a deeply asymmetrical international system. The development discourse imprinted the normative fibre of international society and, by the turn of the century, the idea of development partnership had been widely embraced and institutionalised.

Another normative domain where the African footprint is clearly visible, is that of human security. Individual Africans have provided pioneering leadership in placing human security at the core of the international diplomatic agenda, but this has not reflected at either the African state or society of states level. Indeed, despite pervasive diplomatic rhetoric invoking a range of traditional African values such as community, collectivity, selfless-ness, "Ubuntu", "Harambee" and respect for tradition and continuity, African states have tended to prioritise regime (rather than human) security and solidarity among political incumbents. In some cases, this has also extended to fraternisation with the political elites of former colonial masters. However, controversial diplomatic vacillation by Africa on certain legal matters notably the legitimacy of the ICC in the face of blatant structural power politics has had the beneficial effect that it is forcing wider analysis of normative anomalies at the heart of contemporary international society.

The architecture of contemporary universal international society is much more complex and nuanced than ever before, and apparently impacted also by the particularism evidenced in regions such as Africa. Some of the norms cultivated in the parochial sub-societies can be (and have been) exported to the "older" members of that society. Africa has been surprisingly successful in this regard, and its role within international society deserves much more investigation. 


\section{LIST OF SOURCES}

Addis Fortune 2013. Ethiopian Foreign Missions need urgent restructuring. Distributed by AllAfrica Global Media, and published online on 28 April, $<$ http:// allafrica.com/stories/201304300257.html?viewall=1>, accessed 2 May 2013.

Adler-Nissen, R 2014. "Stigma management in international relations: Transgressive identities, norms, and order in international society", International Organization 68:143-176. http://dx.doi.org/10.1017/S0020818313000337

Adler-Nissen, R 2015. "Just greasing the wheels? Mediating difference or the evasion of power and responsibility in diplomacy", The Hague Journal of Diplomacy 10:22-28. http://dx.doi.org/10.1163/1871191X-12341303

African Union (AU) 2007. African Charter on Democracy, Elections and Governance, adopted by the African Union during the 8th Ordinary Session of the Assembly of the Heads of State and Government convened in Addis Ababa, Ethiopia, 30 January.

Annan, K 2000. "We the peoples - The role of the United Nations in the 21st century", The "Millennium Report" by the Secretary-General of the United Nations, March.

Barston, RP 2006. Modern diplomacy. $3^{\text {rd }}$ ed., London: Pearson/Longman.

Bellamy, AJ 2015. "The responsibility to protect turns ten", Ethics \& International Affairs 29(2):161-185. http://dx.doi.org/10.1017/S0892679415000052

Boutros-Ghali, B 1994. "The marginalisation of Africa". In: WC Olson, The theory and practice of international relations. ${ }^{\text {th }}$ ed., Englewood Cliffs: Prentice Hall.

Bull, H 1977. The anarchical society: A study of order in world politics. New York: Columbia University Press. http://dx.doi.org/10.1007/978-1-349-24028-9

Calvert, S and P Calvert 1996. Politics and society in the Third World: An introduction. London: Prentice Hall.

Chimni, BS 2013. "R2P and Syria: Imperialism with a human face", Open Democracy 11 September, <https://www.opendemocracy.net/openglobalrights/ bschimni/r2p-and-syria-imperialism-with-human-face>, accessed 23 October 2015.

Cohen, R 2001. "The great tradition: The spread of diplomacy in the ancient world", Diplomacy \& Statecraft 12(1):23-38. http://dx.doi.org/10.1080/09592290108406186 
Debrah, EM 1996. "Structuring a regional diplomatic training programme". Keynote address by former Ambassador of Ghana and Commonwealth Consultant on Diplomatic Training to the Southern African Regional Seminar on Diplomatic Training, Pretoria, 29 April-3 May.

Deng, FM 1995. "Frontiers of sovereignty", Leiden Journal of International Law 8(2):249-286. http://dx.doi.org/10.1017/S0922156500003320

Der Derian, J 1987. On diplomacy: A genealogy of Western estrangement. New York: Basil Blackwell.

Eban, A 1998. Diplomacy for the next century. New Haven: Yale University Press.

Hamalengwa, M, C Flinterman and EVO Dankwa (eds) 1988. The international law of human rights in Africa: Basic documents and annotated bibliography. Dordrecht: Martinus Nijhoff.

Heyns, C 1995. "The Preamble of the United Nations Charter: The contribution of Jan Smuts", African Journal of International and Comparative Law 7(2):329-348.

Holsti, KJ 2004. Taming the sovereigns. Institutional change in international politics. Cambridge: Cambridge University Press. http://dx.doi.org/10.1017/CBO9780511491382

Huntington, SP 1996. The clash of civilisations and the remaking of world order. New York: Simon and Schuster.

Hurrell, A 2004. "Working with diplomatic culture: Some Latin American and Brazilian questions". Paper prepared for ISA Meeting, Montreal, March.

Irwin, GW 1975. "Precolonial African diplomacy: The example of Asante", The International Journal of African Historical Studies 8(1):81-96. http://dx.doi. org/10.2307/217487

Jones, E and P Whittingham 1998. "Understanding the World Trade Organisation: Implications and possibilities for the South", Foundation for Global Dialogue, Occasional Paper 13, October.

Jönsson, C and M Hall 2005. Essence of diplomacy. Houndsmill: Palgrave Macmillan.

Kanu, MA 2010. "The indispensability of the basic social values in African tradition: A philosophical appraisal”, OGIRISI 7:149-161. http://dx.doi.org/10.4314/ og.v7i1.57930 
Kappeler, D 2004. "The birth and evolution of a diplomatic culture". In: H Slavik (ed.), Intercultural communication and diplomacy. Malta: DiploFoundation.

Langhorne, R 1998. "History and the evolution of diplomacy". In: J Kurbalija (ed.), Modern diplomacy. Malta: Mediterranean Academy of Diplomatic Studies, University of Malta.

Linklater, A 2010. "The English School conception of international society: Reflections on Western and non-Western perspectives", Ritsumeikan Annual Review of International Studies 9:1-13.

Marsh, R 2013. Understanding Africa and the events that shaped its destiny. Johannesburg: LAPA.

Mulindwa, P 2015. "Africa can't afford third-termism", The Sunday Independent. 20 September, $<$ http://www.ccr.org.za/index.php/media-release/in-the-media/newspaperarticles/ item/1384-africa-third-termism>, accessed 30 September 2015.

Murithi, T (ed.) 2013. Handbook of Africa's international relations. London: Routledge.

Mutton, JF 2015. "Africa and the ICC: countering halftruths", Daily Maverick, 13 July, <http://www.dailymaverick.co.za/opinionista/2015-07-13-africa-and-theicc-countering-half-truths\#.VjPkZTahfIU>, accessed 21 October 2015.

Nanjira, DD 2010. African foreign policy and diplomacy: From antiquity to the $21^{\text {st }}$ century. 2 Volumes. Santa Barbara CA: Praeger.

Neack, L, JAK Hey and PJ Haney 1995. Foreign policy analysis: Continuity and change in its second generation. Englewood Cliffs: Prentice Hall.

Ndlovu-Gatsheni, SJ 2013. Pan-Africanism and the international system. In: T Murithi (ed.), Handbook of Africa's international relations. London: Routledge.

Neumann, IB 2005. “To be a diplomat”, International Studies Perspectives 6(1):72-93. http://dx.doi.org/10.1111/j.1528-3577.2005.00194.x

Neuman, SG (ed.) 1998. International relations. Theory and the Third World. London: Macmillan.

Puchala, DJ 1998. "Third World thinking and contemporary international relations". In: SG Neuman (ed.), International Relations Theory and the Third World. London: Macmillan. 
Rodney, W 1973. How Europe underdeveloped Africa. Dar es Salaam: Tanzanian Publishing House.

Rothgeb, JM 1995. "The changing international context for foreign policy". In: L Neack, JAK Hey and PJ Haney (eds), Foreign policy analysis: Continuity and change in its second generation. Englewood Cliffs: Prentice Hall.

Sharp, P 2009. Diplomatic theory of international relations. New York: Cambridge University Press. http://dx.doi.org/10.1017/CBO9780511805196

Shaw, MN 2008. International Law. $6^{\text {th }}$ ed., Cambridge: Cambridge University Press. http://dx.doi.org/10.1017/CBO9780511841637

Smuts, JC 1918. The League of Nations: A practical suggestion. London: Hodder and Stoughton.

Sofer, S 1988. "Old and new diplomacy: A debate revisited", Review of International Studies 14(3):195-211. http://dx.doi.org/10.1017/S0260210500113269

United Nations General Assembly 1986. Declaration on the Right to Development. A/Res/41/128, 4 December.

United Nations General Assembly 1992. An agenda for peace: Preventive diplomacy, peacemaking and peacekeeping. Report of the Secretary-General, United Nations GA and SC, A/47/277, S/24111, 17 June.

United Nations General Assembly 2000. Report of the Panel on United Nations Peace Operations (The 'Brahimi Report). A/55/305, 21 August.

United Nations General Assembly 2000. United Nations Millennium Declaration. $\mathrm{A} / \mathrm{Res} / 55 / 2,18$ September.

United Nations General Assembly 2001. Global agenda for dialogue among civilisations. A/Res/56/6, 21 November.

Whelan, DJ 2015. “'Under the aegis of man': The right to development and the origins of the New International Economic Order", Humanity, Spring:93-108.

Zarakol, A 2014. "What made the modern world hang together: Socialisation or stigmatisation?", International Theory 6(2), July:311-332. http://dx.doi.org/10.1017/ S1752971914000141 